\title{
HUBUNGAN INFEKSI CACING DENGAN TNF $\alpha$ DAN KADAR HEMOGLOBIN PADA IBU HAMIL
}

\author{
${ }^{1}$ Arif P. Yanto \\ ${ }^{2}$ Damajanty H. C. Pangemanan \\ ${ }^{2}$ Joice N. A. Engka \\ ${ }^{1}$ Kandidat Skripsi Fakultas Kedokteran Universitas Sam Ratulangi Manado \\ ${ }^{2}$ Bagian Fisiologi Kedokteran Universitas Sam Ratulangi Manado \\ Email: aprayudi11_273@rocketmail.com
}

\begin{abstract}
Currently more than 2 billion people infected with worms. High prevalence is found primarily in industrialized countries (developing countries). In Indonesia worms is a public health problem after malnutrition. Worms often associated with deficiency anemia espencially iron deficiency. World Health Organization (WHO) reported that the prevelence of pregnant women who experienced approximately 35-75\% iron deficiency and increased along with increasing gestational age. Burden of disease and morbidity from worm disease is transmitted through the ground is influenced by the highly complex immune response, TNF immune response against bacteria, fungal invasion, viruses and parasites. The research is analytic survey doing by cross sectional study. After that data collected were processed using SPSS. All of the population are pregnant women in 6 working areas of North Bolaang Mongondow district health center and the population sampel section is taken by purposive sampling. By using the chi square test at the $95 \%$ confidence level of this study showed there is a correlation worm infection with TNF $\alpha$ in pregnant women and there is no corelation worm infection with hemoglobin levels in pregnant women. No correlation between worm infections and hemoglobin levels and there is correlation between worm infection with TNF $\alpha$ in pregnant women in North Bolaang Mongondow regency.
\end{abstract}

Keywords: worm infection, $\mathrm{TNF} \alpha$, and $\mathrm{Hb}$.

\begin{abstract}
Abstrak: Saat ini lebih dari 2 miliar penduduk dunia terinfeksi cacing. Prevalensi yang tinggi ditemukan terutama di negara-negara non industri (negara yang sedang berkembang). Di Indonesia cacingan merupakan masalah kesehatan masyarakat setelah malnutrisi. Penyakit cacingan sering dihubungkan dengan kejadian anemia, terutama defisiensi besi. Badan kesehatan dunia World Health Organization (WHO) melaporkan bahwa prevalensi ibu-ibu hamil yang mengalami defisiensi besi sekitar 35-75\% serta semakin meningkat seiring bertambahnya usia kehamilan. Beban penyakit dan angka kesakitan dari penyakit cacing yang ditularkan lewat tanah ini dipengaruhi oleh respon imun yang sangat kompleks. TNF $\alpha$ sebagai respon kekebalan terhadap bakteri, invasi jamur, virus dan parasit. Penelitian dilakuakan bersifat survei analitik dengan rancangan cross sectional study. Selanjtunya data yang terkumpul diolah dengan menggunakan bantuan komputer program SPSS. Populasi adalah semua ibu hamil yang ada di wilayah kerja 6 puskesmas kabupaten Bolaang Mongondow Utara dan sampel di ambil dengan cara purposive sampling. Dengan menggunakan uji Chi Square pada tingkat kepercayaan 95\% Penelitian ini menunjukan ada hubungan infeksi cacing dengan TNF $\alpha$ pada ibu hamil dan tidak ada hubungan infeksi cacing dengan kadar hemoglobin pada ibu hamil. Tidak ada hubungan antara infeksi cacing dengan kadar hemoglobin dan ada hubungan infeksi cacing dengan TNF $\alpha$ pada ibu hamil di Kabupaten Bolaang Mongondow Utara.
\end{abstract}

Kata kunci: infeksi cacing, TNF $\alpha$, dan kadar Hb. 
Saat ini lebih dari 2 milyar penduduk dunia terinfeksi cacing. Prevalensi yang tinggi ditemukan terutama di negara - negara non industri (negara yang sedang berkembang). Badan kesehatan dunia World Health Organization (WHO) mengatakan bahwa diperkirakan 800 juta - 1 milyar penduduk terinfeksi Ascaris, 700 - 900 juta terinfeksi cacing tambang, 500 terinfeksi trichuris. ${ }^{1}$

Di Indonesia cacingan merupakan masalah kesehatan masyarakat setelah malnutrisi, karena Indonesia adalah negara yang agraris dengan tingkat sosial ekonomi, pengetahuan, keadaan sanitasi lingkungan dan higiene masyarakat yang masih rendah yang menyokong untuk terjadinya infeksi dan penularan cacing. ${ }^{1}$

Di Indonesia prevalensi kecacingan masih tinggi antara 60\% - 90\% tergantung pada lokasi dan sanitasi lingkungan. ${ }^{2}$ Penyakit cacingan sering dihubungkan dengan kejadian anemia, terutama defisiensi besi. ${ }^{3}$

Besi merupakan bagian dari molekul hemoglobin, dengan berkurangnya besi maka sintesa hemoglobin akan berkurang dan mengakibatkan kadar hemoglobin akan turun. Hemoglobin merupakan unsur yang sangat vital bagi tubuh manusia, karena kadar hemoglobin yang rendah mempengaruhi kemampuan menghantarkan oksigen yang sangat dibutuhkan oleh seluruh jaringan tubuh. ${ }^{4}$

Kebutuhan besi yang dibutuhkan setiap harinya untuk menggantikan zat besi yang hilang dari tubuh dan untuk pertumbuhan ini bervariasi, tergantung dari umur, jenis kelamin. Kebutuhan meningkat pada bayi, remaja, wanita hamil, menyusui serta wanita menstruasi. Oleh karena itu kelompok tersebut sangat mungkin menderita defisiensi besi jika terdapat kehilangan besi yang disebabkan hal lain maupun kurangnya intake besi dalam jangka panjang. ${ }^{4}$

Sekitar 50\% wanita hamil tidak memiliki cukup zat besi dalam tubuh mereka. Badan kesehatan dunia World Health Organization (WHO) melaporkan bahwa prevalensi ibu-ibu hamil yang mengalami defisiensi besi sekitar 35-75\% serta semakin meningkat seiring dengan pertambah usia kehamilan. ${ }^{4}$ Berkurangnya zat besi dalam makanan, meningkatnya kebutuhan akan zat besi, atau kehilangan darah yang kronis dan adanya infeksi cacing akan menambah kemungkinan timbulnya anemia. ${ }^{3}$

Beban penyakit dan angka kesakitan dari penyakit cacing yang di tularkan lewat tanah ini dipengaruhi oleh respon imun yang sangat kompleks. ${ }^{5}$ TNF $\alpha$ merupakan anggota kelompok sitokin yang merangsang respon fase akut terhadap bakteri gram negatif dan mikroba lainnya, serta pada cedera trauma. Fungsi lain TNF $\alpha$ sebagai respon kekebalan terhadap bakteri, invasi jamur, virus, dan parasit. ${ }^{6}$

\section{METODE PENELITIAN}

Penelitian yang dilakuakan bersifat survey analitik dengan rancangan cross sectional study. Subjek merupakan ibu hamil yang ada di wilayah kerja 6 puskesmas yang ada di kabupaten Bolaang Mongondow Utara dengan kriteria inklusi seluruh ibu hamil trimester 2 dan 3, hadir pada saat diperiksa, dan bersedia menjadi sampel.

Penelitian dilakukan selama bulan September 2014 sampai Januari 2015. Data yang telah didapatkan, kemudian dikumpulkan dan diolah menggunakan analisis univariat untuk mengetahui distribusi frekuensi dan proporsi masingmasing variabel yang diteliti, dan analisis bivariat untuk menunjukkan uji hubungan antara variabel independen (infeksi cacing) dengan variabel dependen (kadar hemoglobin, TNF $\alpha$ ).

Tabel 1 menunjukan bahwa responden penelitian pada trimester 2 sebanyak $25 \mathrm{ibu}$ hamil (35\%) dan pada trimester 3 sebanyak 47 ibu hamil (65\%). Tingkat pendidikan ibu paling banyak SMA yaitu sebanyak 28 responden (39\%) dan paling sedikit S1 yaitu sebanyak 2 responden (3\%), sedangkan pekerjaan ibu dari paling banyak sebagai IRT yaitu 67 responden (93\%) dan paling sedikit sebagai tenaga honorer yaitu 5 responden (7\%). 
HASIL PENELITIAN

\section{Karakteristik Responden}

Tabel 1. Karakteristik responden

\begin{tabular}{ccc}
\hline Karateristik & & \\
Responden & $\mathrm{n}$ & $\%$ \\
Penelitian & & \\
\hline
\end{tabular}

\begin{tabular}{ccc}
\hline Trimester & & \\
2 & 25 & 35 \\
3 & 47 & 65 \\
\hline Pendidikan ibu & & \\
SD & 22 & 30 \\
SMP & 20 & 28 \\
SMA & 28 & 39 \\
S1 & 2 & 3 \\
\hline Pekerjaan ibu & & \\
Honorer & 5 & 7 \\
IRT & 67 & 93
\end{tabular}

\begin{tabular}{ccc}
\hline Pendidikan suami & & \\
SD & 27 & 38 \\
SMP & 22 & 30 \\
SMA & 19 & 27 \\
S1 & 4 & 5 \\
\hline Pekerjaan suami & & \\
Sopir & 4 & 5 \\
PNS & 2 & 3 \\
Petani & 35 & 49 \\
Wiraswasta & 18 & 25 \\
Buruh & 9 & 13 \\
Pekerja swasta & 4 & 5 \\
\hline Pendapatan & & \\
perbulan & 7 & 9,7 \\
$<500.000$ & 38 & 53 \\
$500.000-$ & 26 & 36 \\
900.000 & 1 & 1,3 \\
$1.000 .000-$ & & \\
2.000 .000 & & \\
$>2.000 .000$ & & \\
\hline Total jumlah & 72 & 100 \\
\hline
\end{tabular}

Pada Tabel 1 dapat pula dilihat bahwa tingkat pendidikan suami paling banyak SD yaitu sebanyak 27 orang (38\%), paling sedikit adalah S1 yaitu sebanyak 4 orang (5\%). Pekerjaan suami dari responden penelitian paling banyak sebagai petani yaitu sebanyak 35 orang (49\%) dan paling sedikit PNS yaitu sebanyak 2 orang (3\%).
Pendapatan keluarga responden penelitian paling banyak pada kisaran Rp. 500.000 - 900.000 yaitu 38 orang (53\%) dan paling sedikit adalah $>$ Rp. 2.000 .000 yaitu 1 orang $(1,38 \%)$.

\section{Analisis Univariat}

Tabel 2. Distribusi infeksi cacing pada ibu hamil di Kabupaten Bolaang Mongondow Utara

\begin{tabular}{ccc}
\hline Infeksi cacing & $\mathrm{n}$ & $\%$ \\
\hline Positif & 5 & 7 \\
Negatif & 67 & 93 \\
\hline Total & 72 & 100 \\
\hline
\end{tabular}

Distribusi infeksi cacing pada ibu hamil dapat dilihat pada tabel 2, reponden yang terinfeksi cacing berjumlah 5 ibu hamil (7\%), Sedangkan yang tidak terinfeksi cacing berjumlah 67 ibu hamil (93\%).

Tabel 3. Distribusi kadar hemoglobin pada ibu hamil di Kabupaten Bolaang Mongondow Utara

\begin{tabular}{ccc}
\hline Hemoglobin & $\mathrm{N}$ & $\%$ \\
\hline Rendah & 21 & 29,2 \\
Normal & 51 & 70,8 \\
\hline Total & 72 & 100 \\
\hline
\end{tabular}

Distribusi kadar hemoglobin pada ibu hamil dapat dilihat pada tabel 4, reponden dengan kadar hemoglobin rendah berjumlah 21 ibu hamil (29,2 \%) dan yang memiliki kadar hemoglobin normal berjumlah 51 ibu hamil (70,8\%).

Tabel 4. Distribusi TNF $\alpha$ pada ibu hamil di Kabupaten Bolaang Mongondow Utara

\begin{tabular}{ccc}
\hline TNF $\alpha$ & N & $\%$ \\
\hline Tinggi & 10 & 13,9 \\
Normal & 62 & 86,1 \\
\hline Total & 72 & 100 \\
\hline
\end{tabular}

Distribusi Kadar TNF $\alpha$ pada ibu hamil dapat dilihat pada tabel 5, reponden yang kadar TNF $\alpha$ meningkat berjumlah $10 \mathrm{ibu}$ hamil (13,9\%) dan yang memiliki kadar 
TNF $\alpha$ normal berjumlah 62 ibu hamil $(86,1 \%)$.

\section{Analisis Bivariat}

Tabel 5. Distribusi hubungan infeksi cacing dengan kadar hemoglobin pada ibu hamil di Kabupaten Bolaang Mongondow Utara

\begin{tabular}{ccccrcc}
\hline Infeksi & \multicolumn{4}{c}{ Kadar Hemoglobin } & Total & $P$ \\
\cline { 2 - 5 } Cacing & \multicolumn{2}{c}{ Rendah } & \multicolumn{2}{c}{ Normal } & & \\
\cline { 2 - 5 } & $\mathrm{n}$ & $\%$ & $\mathrm{n}$ & $\%$ & & \\
\hline Positif & 3 & 60 & 2 & 40 & 5 & 0,144 \\
Negatif & 18 & 26,9 & 49 & 73,1 & 67 & \\
\hline
\end{tabular}

Hasil analisis dari 72 responden, menunjukan dari 5 responden yang terinfeksi cacing ada 3 responden (60\%) yang memiliki kadar hemoglobin rendah dan 2 responden (40\%) memiliki kadar hemoglobin normal. Pada 67 responden yang tidak terinfeksi ada 18 responden (26,9\%) dengan kadar hemoglobin rendah dan 49 responden $(73,1 \%)$ dengan kadar hemoglobin normal.

Hasil analisis dari 72 responden, menunjukan ada 5 responden yang terinfeksi dengan peningkatan kadar TNF $\alpha$ berjumlah 5 responden (100\%), sedangkan yang tidak terinfeksi cacing berjumlah 67 responden dengan 5 responden $(7,5 \%)$ memiliki kadar TNF $\alpha$ yang tinggi dan 62 responden $(92,5 \%)$ yang memiliki kadar TNF $\alpha$ yang normal.

Hasil uji Chi Square $\left(\mathrm{X}^{2}\right)$ pada tingkat kepercayaan $95 \%$ menunjukan nilai $p=$ 0,144 pada analisis hubungan infeksi cacing dengan kadar hemoglobin ibu hamil. Nilai $p$ pada analisis hubungan infeksi cacing dengan kadar hemoglobin ibu hamil lebih besar dari nilai $\alpha=0,05$ ini menunjukan bahwa tidak terdapat hubungan antara infeksi cacing dengan kadar hemoglobin pada ibu hamil di Kabupaten Bolaang Mongondow Utara.

Pada analisis hubungan infeksi cacing dengan kadar TNF $\alpha$ ibu hamil menunjukan nilai $p=0,000$. Nilai $p$ pada analisis hubungan infeksi cacing dengan kadar TNF $\alpha$ ibu hamil lebih kecil dari nilai $\alpha=0,05$ ini menunjukan bahwa terdapat hubungan antara infeksi cacing dengan TNF $\alpha$ pada ibu hamil di Kabupaten Bolaang Mongondow Utara. Dengan demikian $\mathrm{H}_{\mathrm{a}}$ dan $\mathrm{H}_{\mathrm{b}}$ diterima sedangkan $\mathrm{H}_{0}$ dan $\mathrm{H}_{\mathrm{c}}$ ditolak.

Tabel 6. Distribusi hubungan infeksi cacing dengan kadar TNF a pada ibu hamil di Kabupaten Bolaang Mongondow Utara

\begin{tabular}{ccccccc}
\hline Infeksi & \multicolumn{4}{c}{ Kadar TNF $\alpha$} & Total & $P$ \\
\cline { 2 - 5 } Cacing & \multicolumn{2}{c}{ Tinggi } & \multicolumn{2}{c}{ Normal } & & \\
\cline { 2 - 5 } & $\mathrm{n}$ & $\%$ & $\mathrm{n}$ & $\%$ & & \\
\hline Positif & 5 & 100 & 0 & 0 & 5 & 0,000 \\
Negatif & 5 & 7,5 & 62 & 92,5 & 67 & \\
\hline
\end{tabular}

\section{BAHASAN}

\section{Hubungan infeksi cacing dengan kadar hemoglobin}

Pada penelitian ini dari survey 72 sampel ibu hamil di kabupaten Bolaang Mongondow Utara, ditemukan 5 orang (7 \%) yang positif terinfeksi cacing dan 67 orang (93 \%) yang tidak terinfeksi cacing. Dari 5 orang yang terinfeksi cacing ada 3 orang (60\%) yang mengalami penurunan kadar hemoglobi sedangkan 2 orang (40 \%) tidak mengalami penurunan kadar hemoglobin. Ibu hamil yang mengalami penurunan kadar hemoglobin berjumlah 21 orang $(29,2 \%)$ dan yang tidak mengalami penurunan kadar hemoglobin berjumlah 51 orang $(70,8 \%)$.

Nilai hemoglobin pada ibu hamil trimester 2 yaitu 10,5 g/dl dan trimester 3 yaitu $11 \mathrm{~g} / \mathrm{dl} .^{7}$ Badan kesehatan dunia WHO melaporkan bahwa pervalensi ibuibu yang mengalami defisiensi besi sekitar 35-75 \% serta semakin meningkat seiring dengan pertambahan usia kehamilan. ${ }^{4}$ Infeksi cacing merupakan masalah kesehatan kedua setelah malnutrisi. ${ }^{1}$ Penyebab tersering kekuranagan kadar hemoglobin adalah difisiensi zat-zat nurisi, seringkali defisiensinya bersifat multipel dengan manifestasi klinik yang disertai infeksi gizi buruk dan kelainan herediter. 
Resiko defisiensi besi meningkat pada kehamilan dan berkaitan dengan asupan besi yang tidak adekuat di bandingkan kebutuhan pertumbuhan janin yang cepat. ${ }^{7}$

\section{Hubungan infeksi cacing dengan TNF $\alpha$}

Dari 72 sampel ibu hamil terdapat 10 orang $(13,9)$ yang mengalami peningkatan TNF $\alpha$ dan yang tidak terjadi peningkatan TNF $\alpha$ berjumlah 62 orang $(86,1)$. Dari 10 orang yang mengalami peningkatan TNF $\alpha$ ada 5 orang ( $50 \%)$ yang positif terinfeksi cacing sedangkan 5 orang (50 \%) lainnya tidak terinfeksi cacing.

Infeksi cacing selain berpengaruh terhadap pemasukan, pencernaan, penyerapan, serta metabolisme makanan, yang dapat berakibat hilangnya protein, karbohidrat, lemak, vitamin dan darah dalam jumlah yang besar, juga menimbulkan gangguan respon imun, menurunnya plasma insulin like growth factor (IGF)-1, meningkatkan kadar serum tumor necrosis factor $\alpha$ (TNF), dan menurunkan konsentrasi hemoglobin rerata. $^{8}$

TNF $\alpha$ adalah protein fase akut yang memiliki fungsi sebagai respon kekebalan terhadap bakteri, virus dan parasit tertentu serta perannya dalam nekrosis tumor tertentu. TNF $\alpha$ yang disekresi oleh makrofag menyebabkan pembekuan darah yang berfungsi melawan infeksi. ${ }^{6}$

Ibu hamil sangat peka terhadap terjadinya infeksi dari berbagai mikroorganisme. Secara fisiologi sistem imun pada ibu hamil menurun, kemungkinan sebagai akibat dari toleransi sistem imun ibu terhadap bayi yang merupakan jaringan semi alogenik meskipun tidak memberikan pengaruh secara klinik. ${ }^{7}$

\section{SIMPULAN}

Dari hasil penelitian yang dilaksanakan di Kabupaten Bolaang Mongondow Utara pada bulan september 2014 sampai januari 2015 maka dapat disimpulkan bahwa:

1. Kadar hemoglobin pada ibu hamil 70,8 $\%$

2. Terdapat hubungan infeksi cacing dengan TNF $\alpha$ pada ibu hamil di Kabupaten Bolaang Mongondow Utara $(0,000)$.

3. Tidak terdapat hubungan infeksi cacing dengan kadar hemoglobin pada ibu hamil di Kabupaten Bolaang Mongondow Utara $(p=0,144)$.

\section{SARAN}

1. Perlu dilalukan penelitian lebih lanjut mengenai hubungan infeksi cacing dengan TNF $\alpha$ dan kadar hemoglobin pada ibu hamil di daerah yang berbeda

2. Memberikan pengobatan kepada ibu hamil yang terinfeksi cacing dan memberikan zat besi bagi ibu hamil

\section{UCAPAN TERIMA KASIH}

Ucapan terima kasih disampaikan kepada semua pihak yang baik secara langsung maupun tidak langsung telah menumbuhkan ide/gagasan dalam pemikiran penulis sehingga dapat menyelesaikan artikel ini.

\section{DAFTAR PUSTAKA}

1. Ginting SA. Hubungan Antara Status Sosial Ekonomi Dengan Kejadian Kecacingan Pada Anak Sekolah Dasar Di Desa Suka Kecamatan Tiga Panah, Kabupaten Karo, Propinsi Sumatera Utara; 2003.

2. Mardiana, Djarismawati. Prevalensi Cacing Usus Pada Murid Sekolah Dasar Wajib Belajar Pelayanan Gerakan Terpadu Pengentasan Kemiskinan Daerah Kumuh Di Wilayah DKI Jakarta. Jurnal Ekologi Kesehatan Vol. 7 No. 2; 2008; p.769 - 774.

3. Rasmaliah. Anemia Kurang Besi Dalam Hubungannya Dengan Infeksi Cacing Pada Ibu Hamil; 2004.

4. Hoffbrand AV. Kapita Selekta Hematologi. Jakarta: EGC; 2005

5. Asemota OO, Morsi PGN, Saac CI, Odoya EM, Akinseye J, Isaac O. Chemokin Responses to Ascaris Lumbricoides sole infection and co infection with Hookworm 
amory Nigeriaus. North. Am. J. Of Med. Sci. Vol 6 Issae 2; 2014. p 84-88.

6. Mathur N, Pedersen BK. Exercise as a Mean to Control Low-Grade Systemic Inflamation. Mediators of Inflamation in UK Pubmed Central. 2009.
7. Prawirohardjo S. Ilmu kebidanan. Jakarta: BP-SP; 2010.

8. Basalamah MF, Pateda V, Rampengan N. Hubungan infeksi soil transmitted helminth dengan kadar hemoglobin anak sekolah dasar GMIM Buha Manado. Jurnal Fakultas Kedokteran Universitas Sam Ratulangi. 2013; p. 2. 